\title{
DISTRIBUTION OF MARINE DEBRIS DURING COVID-19 PANDEMIC AT A PRISTINE ISLAND ON THE ANDAMAN SEA, THAILAND
}

\author{
SORNPLANG, K..$^{1,2}$ - NitiRATSUWAN, T. ${ }^{3}$ - TOWATANA, P. ${ }^{1,2}$ - PRADIT, S. ${ }^{1,2^{*}}$ \\ ${ }^{1}$ Coastal Oceanography and Climate Change Research Center, Faculty of Environmental \\ Management, Prince of Songkla University, Hat Yai, Songkhla, 90110, Thailand \\ ${ }^{2}$ Marine and Coastal Resources Institute, Faculty of Environmental Management, Prince of \\ Songkla University, Hat Yai, Songkhla, 90110, Thailand \\ ${ }^{3}$ Faculty of Science and Fisheries Technology, Rajamangala University of Technology \\ Srivijaya, Trang Campus, Sikao, Trang,-92150, Thailand \\ *Corresponding author \\ e-mail: siriporn.pra@psu.ac.th \\ (Received 23 $3^{\text {rd }}$ Sep 2021; accepted $23^{\text {rd }}$ Nov 2021)
}

\begin{abstract}
The study was conducted with an exploratory study design to explore the amount of debris around beaches on Libong Island, Thailand. Libong Island is one of the significant tourist attractions in Trang Province. The study was conducted by collecting samples from 4 areas during February, June, September and December 2020. The findings from the study showed that 1,580 items of debris were found with a total weight of 44,744 g. The most common debris found included hard plastic glass, fabric, and fibre, respectively. Thung Ya Kha Beach was the beach where the highest amount of debris was found. The largest quantity of debris (692 items) was found in June, followed by 404 items in February, 274 items in September, and 210 items in December. Based on this study, the outstanding debris was comprised of plastic, including 87 types of plastic, both hard and soft varieties, totaling 805 items. No COVID-19 related products were found on the beach, possibly due to a government emergency declaration. Regarding the closure of beaches and the country's lockdown, there were few Thai tourists. There were no foreign tourists in June or September. The result of the waste separation that the major activity causing waste was shoreline and recreation activity.
\end{abstract}

Keywords: marine litter, microplastic, seagrass, plastic, tourist

\section{Introduction}

The amount of waste around the world is constantly increasing as a result of human production and consumption. Seas and oceans play an important role in the longdistance transport of substances and materials, governing the substance and material budget among all the continents. Oceans not only transport heat and chemical compounds but also solid objects and particles floating on or near the surface of water or suspended solids including the spread of life (Maximenko et al., 2019). Seas and oceans are currently threatened by anthropogenic activities resulting in ocean changes, such as rising ocean temperatures and sea level, ocean acidification, biodiversity loss including various pollutants especially plastic pollution (Cauwenberghe et al., 2013). By the middle of the $20^{\text {th }}$ century, there was an increase in commercial plastic production (Geyer et al., 2017; Maximenko et al., 2019). There are 4.8-12.7 million tons of plastic waste transferred from land into the sea (Jambeck et al., 2015). Most of the waste is plastic. It has spread to different areas from the influence of ocean currents and accumulate in the environment, open oceans, coasts and islands, as well as in the deep 
sea (Barnes et al., 2009). This affects the economy, environment, creatures on the coast and in the sea and poses danger to human health (Cauwenberghe et al., 2013; Sheavly, 2007). Over time, these plastic wastes are broken into small pieces. These fragmented plastic wastes are called microplastics (Claessens et al., 2013).

At present, marine debris and microplastics are a major global problem which was mentioned in the Decade of Ocean Science for Sustainable Development (2021-2030) (UNESCO, 2019), proclaimed by the United Nations. As for the Sustainable Development Goals Goal 14.1 aims to prevent and reduce marine pollution of all kinds including marine debris by 2025 (United Nations, 2019). Which prioritizes regional maritime work and collaborating with the G20 Action Plan on Marine Litter. In Thailand, policy recommendations have been made on urgent issues of national interest at sea. Recommendations on marine waste management were presented, which were divided into three main areas: prevention, problem solving and education including: 1) Increasing the capacity of waste collection. The government has to increase waste collection services by waste sorting thoroughly in all communities, both on land and coast, as well as collect garbage on time and regularly, etc. 2) Promoting education. The government must create awareness among the people by publicizing the serious situation of land and marine waste. Marine debris has to be studied and collected in accordance with international principles such as the International Coastal Clean-up (ICC). The obtained information will be definitely used for efficient waste management. Studies on the sources, effects and solutions to the microplastic problem should be carried out as well. People need to be trained on marine debris and microplastics, etc. (Marine Knowledge Database, 2018). In addition, Thailand's roadmap on plastic waste management 2018-2030 to reduce and stop using some types of plastic and recycle them as much as possible (Pollution Control Department, 2018).

However, measures to reduce the amount of plastic waste have changed. Due to the COVID-19 outbreak, the WHO Emergency Committee declared a global health emergency on January 30, 2020, following the high rates of COVID-19 cases in China and other countries. Global Increase (Velavan and Meyer, 2020). Therefore, it is expected that the problem of plastic waste will become more severe both from excessive use and the consumption of single-use plastics (Silva et al., 2021), as well as an increase in the demand for personal protective equipment (PPE) such as masks, rubber gloves, etc., which will also be accompanied by PPE waste after consumption (Okuku et al., 2021). As for Thailand, the first case of COVID-19 was reported on January 12, 2020 (Department of Disease Control, 2020). Therefore, the country has been locked with the government declaring a state of emergency follow by Regulation Issued under Section 9 of the Emergency Decree on Public Administration in Emergency Situations B.E. 2548 (2005) (No. 1). Announced on 25 March 2020 consists of measures do not enter the risk area closing of places that are at risk of disease, such as service places natural attractions, etc., closing the channel into the kingdom. People who are at high risk to stay in housing including refraining from traveling across areas, etc. (Royal Thai Government Gazette, 2020) and canceling measures on 29 May 2020

Libong Island, Trang province, is a coastal community living on fishery resources. Sources of the biggest seagrass beds in Thailand are near the island. It is a significant tourist attraction of Trang province. This is the first study conducted in Thailand around coastal areas of the island having the important ecosystem seagrass and tourist attractions with and without owners, where coastal community-based are located. Therefore, the researchers were interested in studying the type, amount and abundance 
of marine debris on the beaches of Libong Island annually. During the COVID-19 situation of Thailand, since before the lockdown after and before the new wave of COVID-19 outbreak in early 2021. The study result would certainly provide valuable basic information about waste which leads to finding ways to manage marine debris and microplastics in an island ecosystem to prevent and reduce their impacts on fragile ecosystems and living things.

\section{Materials and methods}

\section{Selection of the study area}

Libong Island is located in Thailand at latitude $07^{\circ} 14^{\prime}-07^{\circ} 17^{\prime} \mathrm{N}$ and longitude $99^{\circ}$ $22^{\prime}-09^{\circ} 27^{\prime} \mathrm{E}$, in Trang Province, roughly $2-3 \mathrm{~km}$ from the mainland coast. It is an important tourist attraction in Trang Province. There is a large seagrass source which is the food of the dugong around the island. Libong Island is currently in the Libong Islands Non-Hunting Area, Department of National Parks, Wildlife, and Plant Conservation. Thus, different study areas of four beaches were selected for marine debris collection in this investigation, comprising two to the east and two to the west of Libong Island (Fig. 1).

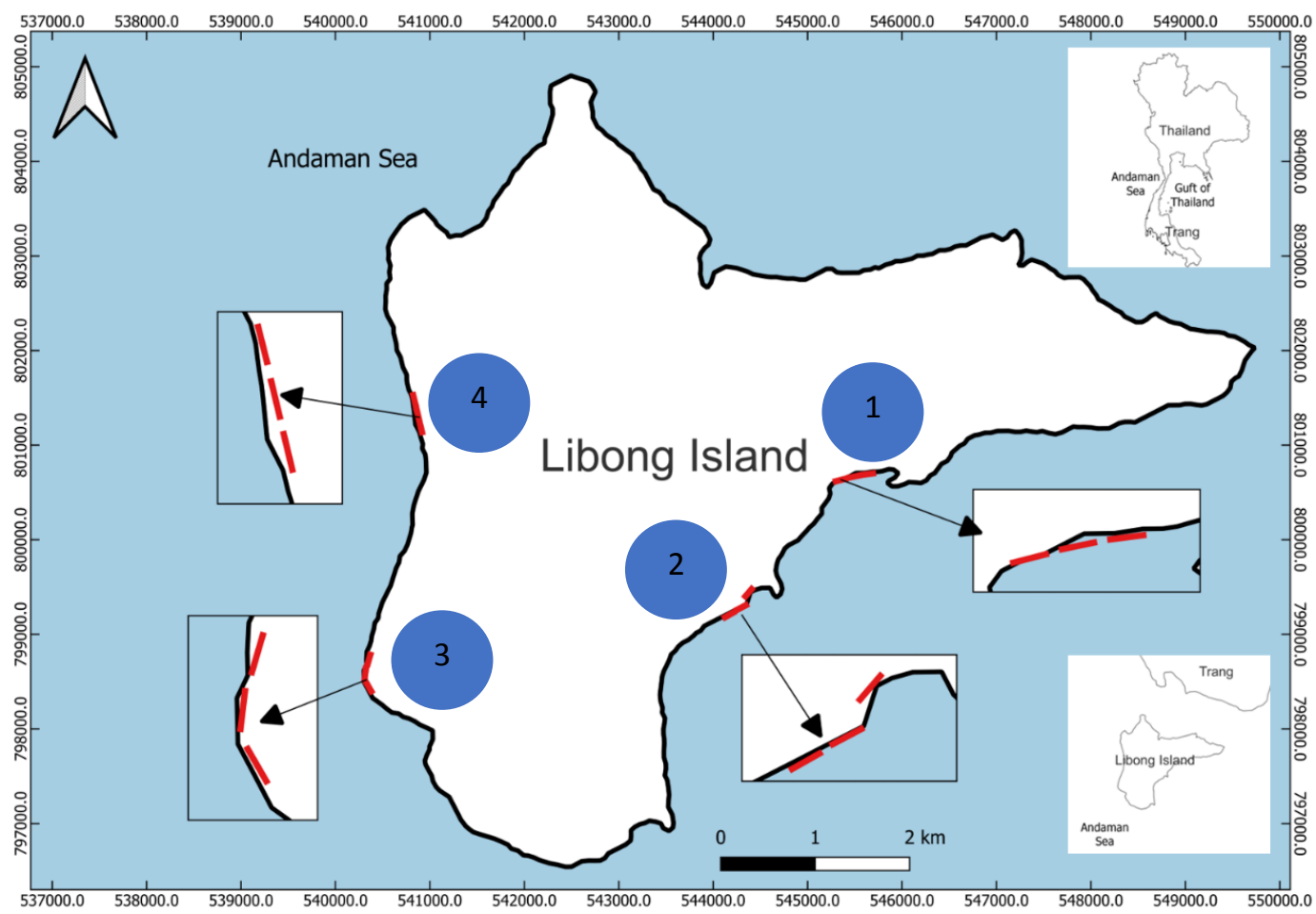

Figure 1. Map of Libong Island with the location of the marine debris collection area: 1 Thung Chin Beach, 2 Libong Camp, 3 Ban Lung Khao and 4 Thung Ya Kha Beach

\section{(1) Thung Chin Beach}

Thung Chin Beach (latitude $7^{\circ} 14^{\prime} 35.961$ 'N longitude $99^{\circ} 24^{\prime} 43.395^{\prime} \mathrm{E}$ ) is to the east of Libong Island, $1 \mathrm{~km}$ away to the east of the Ban Khok Sathon Village with a coastline about $1 \mathrm{~km}$ long. The coastline is sand mixed with shell fragments and next to 
the sandy beach into the sea is a mud beach. There are mangroves growing in this area and next to the muddy beach into the sea is a seagrass area, which is $200 \mathrm{~m}$ to $1,500 \mathrm{~m}$ away from the coastline. It covers a total area of 2,616.8 ha. One unregulated waste disposal site is located approximately $500 \mathrm{~m}$ before reaching Thung Chin Beach. Villagers use the beach as a passageway for local fishing (lobster, shellfish, crab nets) around the seagrass area.

\section{(2) Libong Camp}

Libong Camp (latitude $7^{\circ} 14^{\prime} 35.961^{\prime \prime} \mathrm{N}$ longitude 99'24'43.395' $\mathrm{E}$ ) is on the east side of Libong Island, next to Thung Chin Beach to the south of the island with a 1-km coastal length. The coastline is sand mixed with shell debris. Next to the sandy beach into the sea are rocky and muddy beaches. Next to the mud beach is seagrass (Pradit et al., 2020a,b), with the beachhead area being residential and vacant. In the middle of the beach is the Libong Camp hostel, while at the end of the beach is a cove for a small fishing port in conjunction with a residential area. In addition, villagers use this area for local fishing (collecting shellfish) in the seagrass area.

\section{(3) Ban Lung Khao}

Ban Lung Khao (latitude $7^{\circ} 13^{\prime 2} 28.291^{\prime \prime} \mathrm{N}$ longitude $99^{\circ} 21^{\prime} 54.657^{\prime} \mathrm{E}$ ) is to the west of Libong Island. It has a coastline length of about $800 \mathrm{~m}$. The coastline is sandy. The beach area is a residential area and a small fishing port, which tends to be influenced by high sea waves, causing coastal erosion. Hence, bamboo pole breakwater has been constructed all along the beachhead. In the middle and the end of the beach are hotels and homestays for tourists. The coast is used for leisure activities by tourists during the summer, such as swimming, sunbathing, etc. In addition, villagers take advantage by finding shellfish nearby and on the rocky beaches during low tide.

\section{(4) Thung Ya Kha Beach}

Thung Ya Kha Beach (latitude $7^{\circ} 14^{\prime} 58.019^{\prime} \mathrm{N}$ longitude $99^{\circ} 22^{\prime} 12.728^{\prime \prime} \mathrm{E}$ ) is on the west side of Libong Island and is located in the north of Ban Lung Khao with a coastline length of about $800 \mathrm{~m}$. The coastline is a fine sandy beach. The coast is used for leisure activities by tourists during the summer including walking, taking pictures, etc. The steep slope of the beach is generated by the strong waves of the sea and therefore makes it unsuitable for swimming.

\section{Survey method}

Four sampling periods were conducted to cover all seasons in 2020. The Andaman coast is influenced by the southwest monsoon. May to mid-October experiences heavy rain, waves, and strong winds in the sea and therefore is not suitable for tourism, whereas mid-October to February is the tourist season for Libong Island (Department of Marine and Coastal Resources, 2013). Due to the COVID-19 pandemic, Thailand had a nationwide lockdown from April to May 2020. Thus, the researchers had to postpone the collection of samples. The actual samples were collected during February (before lockdown), June (after lockdown), September (after lockdown) and December 2020 (before the COVID-19 pandemic in 2021). Samples at each station were collected from the shoreline with three transects lined up, each being $100 \mathrm{~m}$ long and $1 \mathrm{~m}$ wide at the 
highest tide. Each survey was carried out by collecting all visible garbage excluding compostable waste, while buried garbage and large pieces/areas of garbage were photographed without collecting. The sample location was defined using the freeware program QGIS and then exported to a KML file for use. The exported file was opened with an application on a mobile phone called MAPinr. Subsequently, the garbage samples were collected along the defined lines.

\section{Classification of marine debris}

Marine waste collected was recorded in a data sheet modified from NOAA (Lippiatt et al., 2013). The collected waste was classified, counted, and weighed. The marine waste was divided into nine categories including hard plastic, thin plastic, fabric and fibre, foam, polymer compounds, glass and ceramics, metals, paper, etc. (unclassifiable/mixed materials). Furthermore, marine debris was also divided according to its origin into 6 sources, namely coastal activities and leisure, marine activities, smoking activity, sanitary equipment (including COVID-19 related such as gloves, masks, liquid hand wash and alcohol-based sanitiser bottles, etc.), large-scale debris disposal activity and other activities (Ocean Conservancy Start a Sea Change, 2009).

\section{Results and discussion}

\section{Type and amount of marine debris}

The survey results of marine debris on the coast of Libong Island showed a total amount of marine debris from all categories of 1,580 items at a total weight of 47,744 g. The largest quantity of marine debris was found in June (692 items), followed by February (404 items), September (274 items) and December (210 items). The areas where samples were collected and had the largest quantity of marine debris during the study were Thung Ya Kha Beach (568 items), followed by Ban Lung Khoa (444 items), Libong Camp (440 items) and Thung Chin Beach (128 items). The study results in each area of study during each month found that Thung Ya Kha Beach had the largest amount of marine debris in June (389 items), February (111 items), and September (51 items). Ban Lung Khoa had the largest quantity of marine debris in September (142 items), February (121 items) and December (103 items), Libong Camp: June (167 items), February (124 items), December (76 items), Thung Chin Beach: June (52 items), February (48 items) and December (14 items).

The total number of hard plastics was 709 items, weighing $10,278 \mathrm{~g}$, followed by 240 items of glass with the highest weight of $10,714 \mathrm{~g}$, and fabric and fibre (123 items) weighing 10,667 $\mathrm{g}$ (Fig. 2). The highest quantity of hard plastic was found on Thung Chin Beach almost every month, comprising $50.785 \%$ overall, followed by thin plastic (13.285\%), and an equal quantity of fabric and fibre and metal (11.725\%), except during September, when fabric and fibre and foam were found in equal amounts. Glass was found the most every month in Libong Camp (33.185\% overall), followed by hard plastic (23.865\%) and polymer (12.505\%). In June, hard plastic was found the most. During December, unidentified debris was found in Ban Lung Khoa the most, but the largest quantity of hard plastic was found overall $(31.535 \%)$, followed by glass (15.325\%), and unidentified debris (13.515\%). The largest quantity of hard plastic was found each month in Thung Ya Kha Beach, totalling $70.255 \%$, followed by foam $(10.745 \%)$, and fabric and fibre $(6.345 \%)$. 

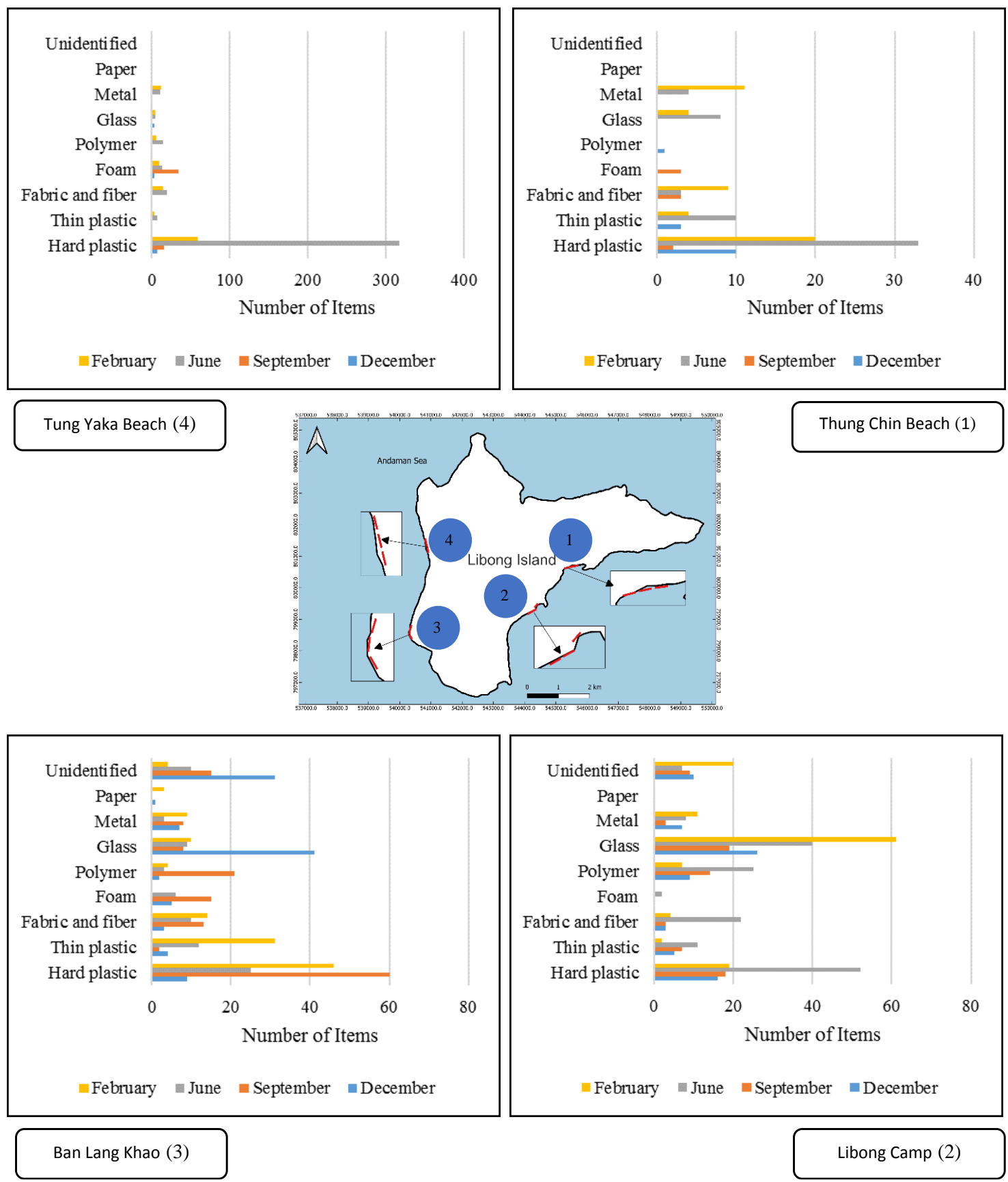

Figure 2. Type and amount of marine debris found in the study area during the whole year

The most common type of marine debris found at almost all the sample stations was hard plastic, except for Libong Camp, at which the most found type was glass. Since Libong Camp has communities located near it, glass found included decomposed glass from drinking bottles in clear, amber, and green colours, totalling 127 items. The study results supported a previous study conducted by Pradit et al. (2020b) on marine debris during May-August 2019 on the beach of Libong Camp, which found that glass was the most outstanding marine debris in the area totalling 699 items. The accumulation of marine debris on beaches results from various factors, including currents in the areas and coastal currents, the slope and length of beaches, levels of current and flowing wind 
(Mobilik et al., 2016). Debris swept into the ocean will partially sink immediately and accumulate wherever it went into the ocean for the first time. However, there is a large quantity of marine debris floating on the ocean surface that perhaps gets moved out of old places (Gonulal et al., 2016; Mobilik et al., 2016). This study found that plastic debris tends to be lightweight. Strong wind and waves from the ocean may sweep plastic debris from the ocean or nearby coasts to beaches, while decomposed glass and ceramic sink into the sand. When weather conditions do not facilitate strong winds or rain, the glass will get dug and scatter on coasts (Simeonova and Chuturkova, 2019). In addition, wind may sweep fabric into the ocean for areas of the study located near communities. Once fabric gets wet, it will absorb water and sink into the ocean.

\section{Distribution of marine debris per area}

Seasonal marine debris distribution at each surveyed beach was determined. The coastline of Libong Island is presented in Figure 3. The results revealed that the highest density of marine debris was in June. Thung Ya Kha Beach had 6.1297 items $/ 100 \mathrm{~m}^{2}$, followed by Libong Camp at 67.55 items $/ 100 \mathrm{~m}^{2}$, Ban Lung Khao at 26.00 items $/ 100 \mathrm{~m}^{2}$ and Thung Chin Beach at 19.33 items $/ 100 \mathrm{~m}^{2}$. Libong Camp showed the highest density of marine debris in February with 41.33 items $/ 100 \mathrm{~m}^{2}$. For Ban Lung Khao, the highest density of marine debris was found during September and December at 47.33 items $/ 100 \mathrm{~m}^{2}$ and 34.33 items $/ 100 \mathrm{~m}^{2}$, respectively. During June, every station had the highest density of marine debris almost every month except Ban Lang Khoa since it was the period that Thailand had just cancelled the lockdown measures due to the COVID-19 situation, so a small number of tourists were found in the area. The density of marine debris during the COVID-19 situation was small compared to the density of marine debris during the COVID-19 situation in Kenya on beaches in urban areas, which ranged between 0.00 and $3.8 \times 10^{2}$ items $\mathrm{m}^{2}$ and on beaches in distant areas that ranged between 0.00 and $5.6 \times 10^{2}$ items $\mathrm{m}^{2}$ (Okuku et al., 2021). A study conducted by Pradit et al. (2020b) reported that the clean coastal index (CCI) of the sandy beach of Libong Island was classified as moderately clean, while the mud beach was classified as very clean.

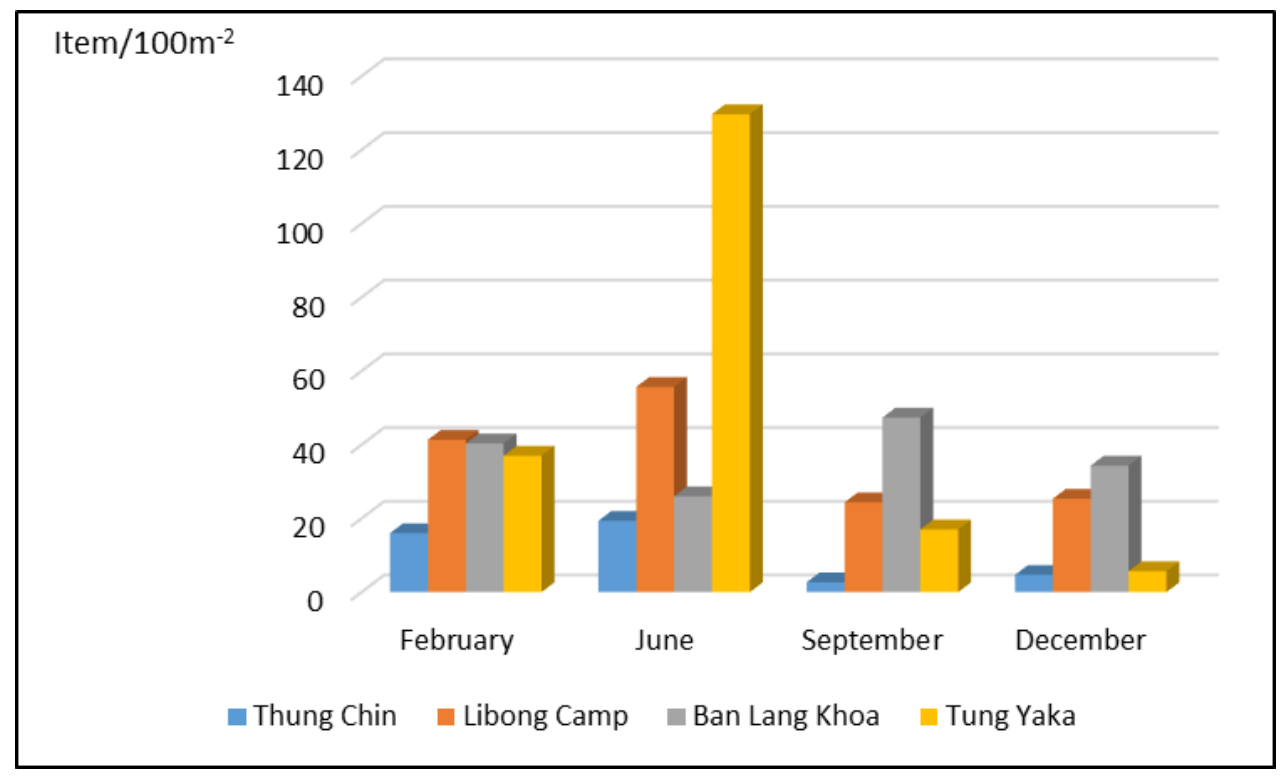

Figure 3. Distribution of marine debris in the study area 


\section{Source of marine debris}

The collected marine waste was divided into six categories, as reported by the ICC (2009) (Fig. 4). Shoreline and recreational are the largest sources of marine debris and the most prominent sources of marine debris among all the study stations on the Libong coast, which amounted to $64.875 \%$ and weight accounting for $62.825 \%$, followed by $16.525 \%$ of other activities. Weight accounted for $4.905 \%$ and ocean and waterway amounted to $8.805 \%$ and weight accounted for $18.535 \%$. Here, 5outstanding types of marine debris are presented according to activities. Some activities produce only 3 types of marine debris found in the areas of study and were conducted during the study, as shown in Table 1. As for shoreline and recreational activities, the most commonly found marine debris is glass, followed by food packages such as snack bags, foam food containers, etc, and bottle caps/stoppers such as water bottle caps, seasoning, or spice bottle caps, etc. An example of the marine debris found in the study areas is shown in Figure 5.

Table 1. Outstanding marine debris classified by sources of origin at Libong Island in 2020

\begin{tabular}{|c|c|c|c|c|c|}
\hline & Thung Chin Beach & Libong Camp & Ban Lung khao & Thung Ya Kha Beach & Total (item) \\
\hline \multicolumn{6}{|l|}{ 1. Shoreline and recreational } \\
\hline 1.1 Glass bottle & 11 & 127 & 55 & 11 & 204 \\
\hline 1.2 Food package & 19 & 25 & 57 & 46 & 147 \\
\hline 1.3 Bottle cap/stopper & 6 & 5 & 10 & 89 & 110 \\
\hline 1.4 Household consumption product & 3 & 60 & 30 & 15 & 108 \\
\hline 1.5 Plastic bag & 16 & 24 & 49 & 11 & 100 \\
\hline \multicolumn{6}{|l|}{ 2. Ocean and waterway } \\
\hline 2.1 Rope/fish net/seine & 9 & 7 & 20 & 22 & 58 \\
\hline 2.2 Buoy & 0 & 2 & 3 & 16 & 21 \\
\hline 2.3 Battery & 0 & 8 & 1 & 0 & 9 \\
\hline 2.4 Sponge & 0 & 1 & 0 & 7 & 8 \\
\hline 2.5 Fertilizer sack/coated sack & 2 & 1 & 4 & 1 & 8 \\
\hline \multicolumn{6}{|l|}{ 3. Smoking related } \\
\hline 3.1 Lighter & 0 & 1 & 3 & 21 & 25 \\
\hline 3.2 Cigarette pack & 0 & 0 & 1 & 1 & 2 \\
\hline 3.3 Tobacco pack & 0 & 0 & 1 & 0 & 1 \\
\hline \multicolumn{6}{|l|}{ 4. Medical and personal hygiene } \\
\hline 4.1 Medicine plastic pack & 1 & 0 & 7 & 6 & 14 \\
\hline 4.2 Medicine glass bottle & 0 & 1 & 1 & 2 & 4 \\
\hline 4.3 Diaper & 0 & 2 & 0 & 0 & 2 \\
\hline \multicolumn{6}{|l|}{ 5. Large-scale debris disposal activity } \\
\hline 5.1 Construction material & 0 & 44 & 59 & 1 & 104 \\
\hline 5.2 Zinc roofing sheet & 0 & 1 & 1 & 0 & 2 \\
\hline 5.3 Vehicle tire & 1 & 0 & 0 & 0 & 1 \\
\hline \multicolumn{6}{|l|}{ 6. Other } \\
\hline 6.1 Plastic scrap & 4 & 16 & 21 & 124 & 165 \\
\hline 6.2 Foam scrap & 3 & 2 & 23 & 48 & 76 \\
\hline 6.3 Rubber scrap & 0 & 5 & 5 & 3 & 13 \\
\hline 6.4 Wire & 0 & 3 & 3 & 1 & 7 \\
\hline 6.5 Sack scrap & 0 & 1 & 1 & 1 & 3 \\
\hline
\end{tabular}




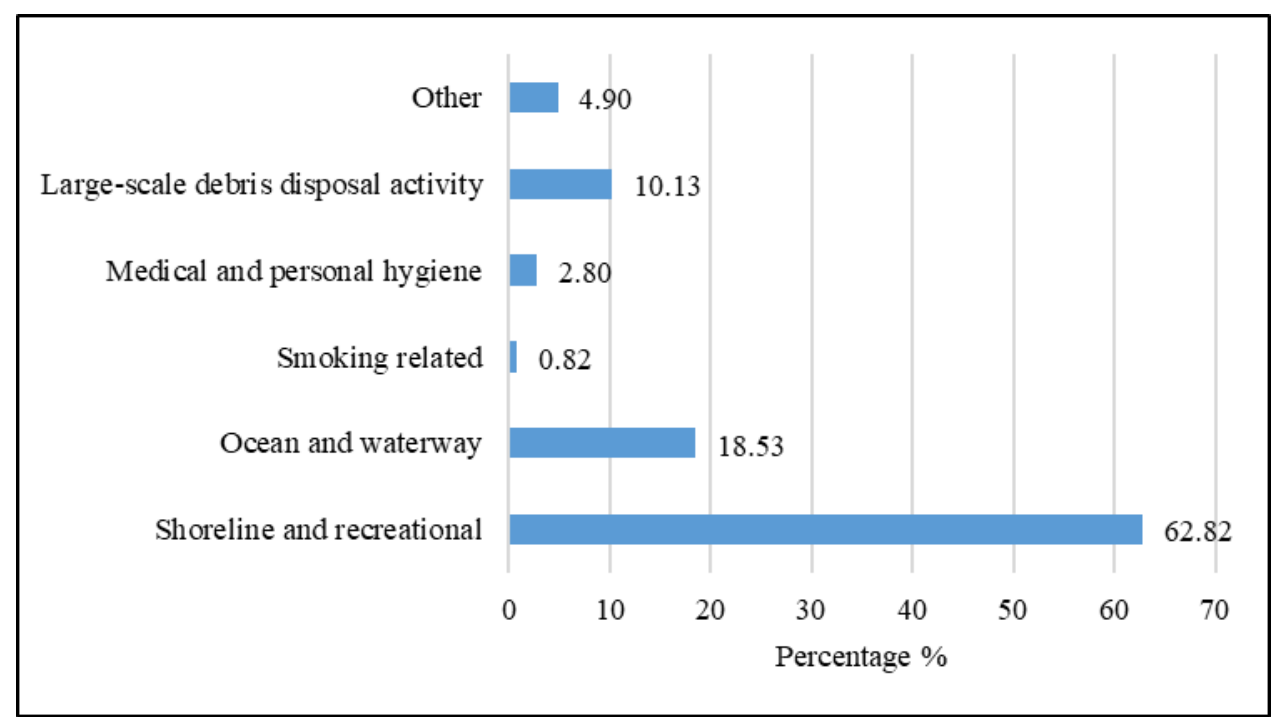

Figure 4. Sources of marine debris

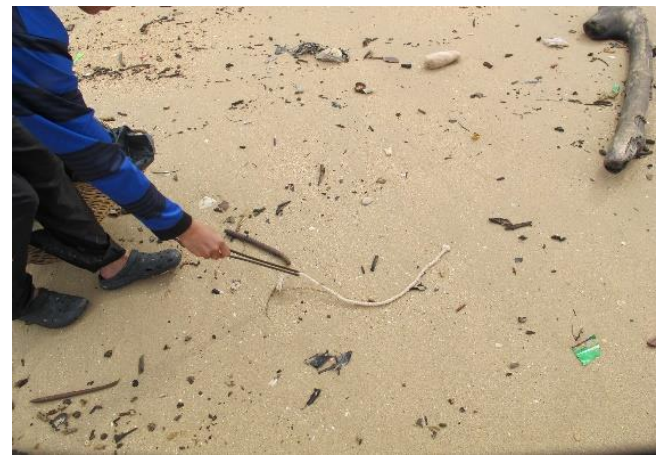

(a)

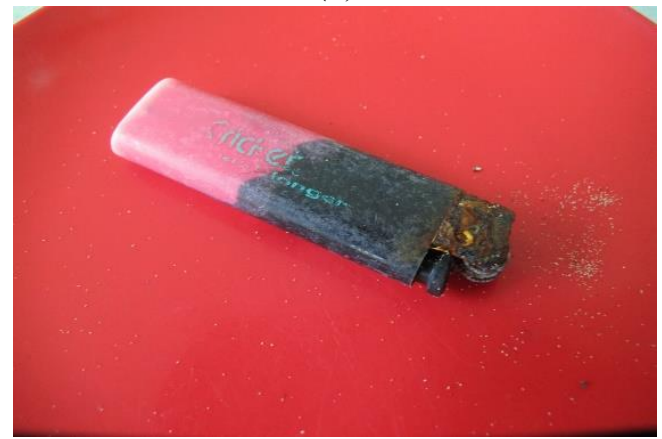

(c)

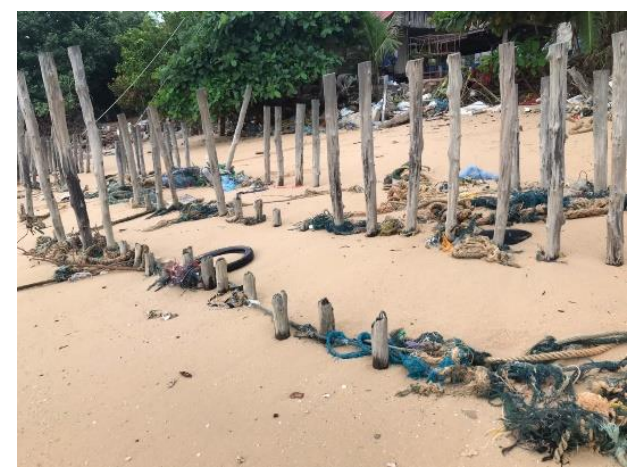

(b)

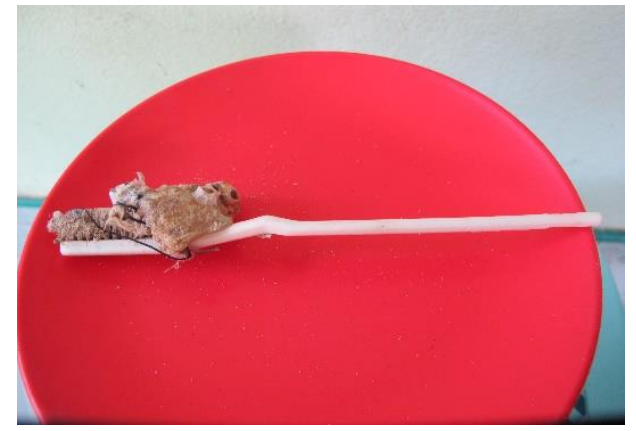

(d)

Figure 5. Example of marine debris found in the study areas

In the areas of study, no waste related to COVID-19 was found such as masks, bottles of hand sanitiser, and alcohol-based sanitiser bottles. A study on the density of marine debris during the COVID-19 situation conducted by Okuku et al. (2021) showed that such types of debris were not found in some areas of study. As for large-scale debris disposal activity, the most outstanding debris are construction materials such as brick scraps, cement waste, gypsum board scraps, and other waste that cannot be 
identified types of activity such as hard plastic scraps, foam scraps, and rubber scraps. According to previous studies, sources of marine debris were shoreline and recreational activities (Pervez et al., 2020). A study conducted by Kumar et al. (2016) revealed that the sources of marine debris from shoreline and recreational activities accounted for $74.465 \%$. Shoreline activities and tourism play an important role in producing coastal debris resulting from waste disposal behaviours (Pervez et al., 2020; Kumar et al., 2016).

Based on this study, outstanding marine debris are plastics, 87 types of both hard and soft plastics, totalling 805 items. A comparison of the top 20 marine debris calculated from the number of items (Table 2) indicated that the marine debris with the highest distribution were hard plastics (types of plastic could not be identified), 160 items (23.055\%), which were found the most in June, followed by September and February. The second was plastic carrier bags at 102 items (14.705\%), which were found the most in June, followed by February with similar items, and December respectively. Third place was the same number of plastic water bottles and bottle caps, 59 items (8.505\%), which were found the most in June, followed by plastic water bottles, which were found in September, and February and December at the same number, followed by water bottle caps, which were found in February and September. The fourth was seasoning or spice bottle caps at 45 items $(6.485 \%)$, which were found the most in June, followed by September. Comparison with the 2019 study results of Pradit et al. (2020b) around beaches, stone beaches, and mud beaches in Libong Island, other plastics $(30.085 \%)$ were found the most, followed by plastic bags (25.965\%), and plastic bottles (15.685\%), respectively.

Comparing marine plastic waste to previous studies by Pradit et al. (2020b) in the Libong Island area during the COVID-19 outbreak in Thailand, only marine debris that can be classified will be discussed. The predominant plastic waste in the area was plastic bags, which were found in both previous studies and at the beginning of this study. Every time there is a survey, it will observe that condiment caps peaked in June, with very few in other months. This corresponds to the period after the lockdown that more people are staying at home. As a result, there is also an increase in household cooking.

From this study, an overview study of marine debris on the coast of Koh Libong, Trang Province during the COVID-19 situation of 2020 can be summarised as shown in Table 3. It was found that the amount of marine debris during June, after the lockdown announcement, the amount of waste was found to be higher than the previous month (February) because it was the time when everyone was at home. Consequently, consumption increases, so it may be garbage that accumulates during the lockdown period. In addition, the COVID-19 situation in 2020 resulted in a shortage of masks and, thus, more expensive prices. Other PPE products also saw similar situations, so most people used cloth masks as they tended to be cheap and could be used many times. Therefore, it may be one of the reasons that PPE waste was not found in the study area, including the country's lockdown measures (lockdown period) affecting Trang Province in June and September. During the COVID-19 outbreak in Thailand with the government lockdown order, there was no inter-provincial travel and no activity of both private and government organisations for approximately 3 months. Thus, this certainly changed people's lifestyles by causing them to stay at home and work from home, resulting in more laundry activities, releasing more cloth fibres into the drain water, and finally entering the environment (Pradit et al., 2021). Compared to the amount of 
marine debris found at Libong Camp beach before COVID-19 pandemic (June 2019) while the number of tourists remained unrestricted, there were 579 items (Pradit, 2020b), but in June 2020 (this study) 167 items of marine debris were found on the same beach, which a decrease of about five times.

Table 2. The top 20 marine debris along the coasts of Libong Island in 2020

\begin{tabular}{|c|c|c|c|c|c|c|c|}
\hline No. & List & February & June & September & December & Total & Percentage \\
\hline 1 & $\begin{array}{c}\text { Hard plastic (types of } \\
\text { plastic could not be } \\
\text { identified) }\end{array}$ & 14 & 118 & 22 & 6 & 160 & 23.05 \\
\hline 2 & Plastic carrier bag & 40 & 44 & 8 & 10 & 102 & 14.70 \\
\hline 3 & Water bottle & 11 & 24 & 13 & 11 & 59 & 8.50 \\
\hline 4 & Water bottle cap & 14 & 36 & 6 & 3 & 59 & 8.50 \\
\hline 5 & $\begin{array}{l}\text { Seasoning or spice } \\
\text { bottle cap }\end{array}$ & 1 & 39 & 4 & 1 & 45 & 6.48 \\
\hline 6 & Clear plastic bag & 21 & 14 & 0 & 1 & 36 & 5.19 \\
\hline 7 & Plastic straw & 10 & 15 & 4 & 0 & 29 & 4.18 \\
\hline 8 & Clear plastic glass & 13 & 12 & 1 & 0 & 26 & 3.75 \\
\hline 9 & Lighter & 3 & 19 & 2 & 1 & 25 & 3.60 \\
\hline 10 & Fruit juice bottle & 10 & 11 & 2 & 1 & 24 & 3.46 \\
\hline 11 & Toy & 0 & 15 & 6 & 1 & 22 & 3.17 \\
\hline 12 & Fork and spoon & 2 & 18 & 1 & 0 & 21 & 3.03 \\
\hline 13 & Coca-Cola bottle & 3 & 13 & 1 & 1 & 18 & 2.59 \\
\hline 14 & Plastic jelly cup & 4 & 8 & 4 & 0 & 16 & 2.31 \\
\hline 15 & Plastic label & 1 & 1 & 12 & 1 & 15 & 2.16 \\
\hline 16 & $\begin{array}{c}\text { Plastic } \\
\text { pendulum/buoy }\end{array}$ & 4 & 6 & 0 & 0 & 10 & 1.44 \\
\hline 17 & Plastic sack & 3 & 4 & 1 & 1 & 9 & 1.30 \\
\hline 18 & Plastic medicine bottle & 1 & 6 & 1 & 0 & 8 & 1.15 \\
\hline 19 & Food container & 0 & 2 & 2 & 1 & 5 & 0.72 \\
\hline 20 & $\begin{array}{l}\text { Medicine sachet, } \\
\text { medicine pack }\end{array}$ & 0 & 0 & 5 & 0 & 5 & 0.72 \\
\hline & Total & 155 & 405 & 95 & 39 & 694 & 100 \\
\hline
\end{tabular}

Only for Thai tourists by June, there were fewer Thai tourists. Compared to the same period the previous year (2019), 92 per cent had no income from foreign tourists. The income from Thai tourists accounted for 93.5 per cent compared to the monsoon season, it was found June was the period where the largest quantity of marine debris was found since June is the beginning of southwest monsoon season, strong wind and high wave sweep debris in the ocean to coasts but in September, a monsoon period, the small amount of marine debris is found since strong wind and wave in the ocean sweep most of the debris to the lines of beach morning glory above line transect where samples were collected. 
Table 3. The situation of COVID-19 in 2020 and the occurrence of marine debris on the coast of Libong Island

\begin{tabular}{|c|c|c|c|c|}
\hline Factor & $\begin{array}{c}\text { February } 2020 \text { (before } \\
\text { lockdown) }\end{array}$ & $\begin{array}{c}\text { June } 2020 \text { (after } \\
\text { lockdown) }\end{array}$ & $\begin{array}{c}\text { September } 2020 \text { (after } \\
\text { lockdown) }\end{array}$ & $\begin{array}{c}\text { December } 2020 \text { (before } \\
\text { new lockdown) }\end{array}$ \\
\hline $\begin{array}{l}\text { Amount of marine } \\
\text { debris (this study) }\end{array}$ & $\prod_{404 \text { items }}$ & $\left.\left.\right|_{692 \text { items }}\right|_{\text {. }}$ & $\varlimsup_{274 \text { items }}^{4}$ & $\begin{array}{c}\downarrow \\
210 \text { items }\end{array}$ \\
\hline \multirow{8}{*}{$\begin{array}{l}\text { COVID-19 pandemic } \\
(2020)\end{array}$} & \multicolumn{4}{|c|}{ Face masks } \\
\hline & - No face mask used & $\begin{array}{l}\text { - Face masks are in short } \\
\text { supply and expensive }\end{array}$ & $\begin{array}{l}\text { - Face masks are in short } \\
\text { supply and expensive }\end{array}$ & $\begin{array}{l}\text { - Face masks are in short } \\
\text { supply and expensive }\end{array}$ \\
\hline & \multicolumn{4}{|c|}{ Tourists* } \\
\hline & $\begin{array}{l}\text { - Thai (down from the } \\
\text { previous year by } 12.9 \% \text { ) }\end{array}$ & $\begin{array}{l}\text { - Thai (down from the } \\
\text { previous year by } 92.0 \% \text { ) }\end{array}$ & $\begin{array}{l}\text { - Thai (down from the } \\
\text { previous year by } 34.3 \% \text { ) }\end{array}$ & $\begin{array}{l}\text { - Thai (down from the } \\
\text { previous year by } 52.0 \% \text { ) }\end{array}$ \\
\hline & $\begin{array}{l}\text { - Foreigner (decrease } \\
\text { from the previous year } \\
29.9 \% \text { ) }\end{array}$ & • Foreigner (none) & - Foreigner (none) & $\begin{array}{l}\text { - Foreigner (decrease } \\
\text { from the previous year } \\
99.7 \% \text { ) }\end{array}$ \\
\hline & \multicolumn{4}{|c|}{ Income from tourists* } \\
\hline & $\begin{array}{l}\text { - Thai (down from the } \\
\text { previous year by } 12.9 \% \text { ) }\end{array}$ & $\begin{array}{l}\text { - Thai (down from the } \\
\text { previous year by } 93.5 \% \text { ) }\end{array}$ & $\begin{array}{l}\text { - Thai (down from the } \\
\text { previous year by } 37.9 \% \text { ) }\end{array}$ & $\begin{array}{l}\text { - Thai (down from the } \\
\text { previous year by } 52.43 \% \text { ) }\end{array}$ \\
\hline & $\begin{array}{l}\text { - Foreigner (decrease } \\
\text { from the previous year } \\
29.89 \%)\end{array}$ & - Foreigner (none) & - Foreigner (none) & $\begin{array}{l}\text { - Foreigner (decrease } \\
\text { from the previous year } \\
99.9 \% \text { ) }\end{array}$ \\
\hline Monsoon season & Pre monsoon & Before monsoon & Inter monsoon & Post monsoon \\
\hline
\end{tabular}

A study conducted by Alvarez et al. (2020) helped to confirm the information that the areas with the greatest marine debris accumulation comprise areas that are higher than the highest water level and where the tide is at its highest level. In December, there is a small quantity of marine debris as it is a post-monsoon period. The wind blows from the northeast direction and sweeps marine debris from the coasts into the ocean. Villagers living in Libong Island call this wind "Lom oak" (wind blows from the coast to sea). Although Thung Ya Kha Beach is located far from communities, the largest quantity of marine debris was found since Thung Ya Kha Beach is located on the west coast of the island. It is an open beach influenced by the southwest monsoon the most as well as Ban Lung Khoa is located on the west coast of the island. However, since Ban Lung Khoa is located near communities, some parts of marine debris are from communities. This study found construction materials such as floor tile scraps, roof tile scraps, louvre glass scraps, cement waste, and ceramic ware scraps. A small quantity of marine debris was found on the beaches in front of hotels since they are cleaned by hotel staff every day. Libong Camp and Thung Chin Beach are located on the east coast of the island. They look like coves and are less likely to be influenced by the southwest monsoon. Both beaches are quite clean with numerous natural features. They have restrictions for access, making them have low pressure from humans (Alvarez et al., 2020; Pradit et al., 2020b).

The model of wind flow in the areas of the study is similar to that of Malaysia. A study conducted by Mobilik et al. (2016) found a large quantity of marine debris was found during the southwest monsoon period compared to the northeast monsoon period in conjunction with the movement of ocean current in the form of anti-clockwise direction that slightly circulates during the northeast monsoon period but moves in the form of clockwise direction during the southwest monsoon period. The movement of wind and waves is a factor distributing marine debris; previous studies help support this 
subject very well. Comparison of data related to the quantity of marine debris of any beach to the prevalence of marine debris from other beaches in the world seems to be difficult due to different methods and random sampling techniques including other causes such as closeness with inhabited areas. The quantity of debris or waste is related to the congestion of the population, the number of tourists (Gonulal et al., 2016; Pervez et al., 2020), and recreational activities. The quantity of waste is in contrast to the distance of inhabited areas (Veerasingam et al., 2020), environmental factors especially wind velocity and sociological factors such as environmental awareness of beach users (Mobilik et al., 2016).

As there are large seagrass beds nearby Libong Island, the accumulation of plastics in the seagrass bed will have an impact on marine animals in the shallow water ecosystem if the level of marine debris accumulation is high (Bonanno and OrlandoBonaca, 2020). It is a severe threat to marine mammals, sea turtles, and sea birds (Alshawafi et al., 2017; Bonanno and Orlando-Bonaca, 2020; Haram et al., 2020; Mobilik et al., 2016; Veerasingam et al., 2020). A study conducted by Veerasingam et al. (2020) identified that regular beach activity and long-term marine debris monitoring could help reduce marine debris along the coastlines. Therefore, long-term marine debris monitoring along the coastlines of Libong Island would be useful for collecting data related to a tendency of marine debris accumulation along coastlines, which will help improve national policies and measures on marine debris management to be consistent with the future goal of reducing plastic waste in Thailand's roadmap on plastic waste management 2018-2030. Rayon-Vina et al. (2019) proposed a guideline to solve marine debris problems, starting from raising people's awareness. Everyone must be aware that they are a part of the problems and problem-solving guidelines.

\section{Conclusion}

Thung Ya Kha Beach is where the most marine debris found and found the highest amount of marine debris in June. Though it is a beach where tourism activities were more reduced than the previous year due to COVID-19 situations and the country lockdown, the period going to enter southwest monsoon season is the period having a higher quantity of marine debris than monsoon period, the same period when the country lockdown was eased. In this study, no COVID-19 related waste was found. Most of marine debris came from shoreline and recreational activities. A campaign raising people's awareness aims to adjust people's attitudes towards environment. Emphasis should be placed on making understanding of beach status in their locality in order to help encourage people to see how important beaches are before implementing activities together. Local administrative organizations probably consider data from this study for planning management and raising a campaign to make Libong Island become a significant tourist attraction in conjunction with prosperous natural resources seagrass beds and primitive way of life of coastal community for facilitating tourists in the future. Since the floating waste can be transferred by the streams and waving and the landing of the waste materials on the beaches is influenced mainly by weather conditions (wind direction) and wave direction. Further study should include those factors for better understand the source and transport of marine debris.

Acknowledgements. This study was funded by the graduate school, Prince of Songkla University, for thesis research grants on the topic of community solutions in 2020 and Coastal Oceanography and 
Climate Change Research Center. Researcher are thankful to the Department of National Parks, Wildlife and Plant Conservation for allowing us to conduct the research at Libong Island. Thank you to all the research team who helped collect the samples. We express many thanks to reviewers for assisting us to improve the quality of manuscript.

\section{REFERENCES}

[1] Alshawafi, A., Analla, M., Alwashali, E., Aksissou, M. (2017): Assessment of marine debris on the coastal wetland of Martil in the North-East of Morocco. - Marine Pollution Bulletin 117: 302-310.

[2] Alvarez, S., Gestoso, I., Herrera, A., Riera, L., Canning-Clode, J. (2020): A comprehensive first baseline for marine litter characterization in the Madeira Archipelago (NE Atlantic). - Water, Air \& Soil Pollution 231(4): 182.

[3] Barnes, D. K. A., Galgani, F., Thompson, R. C., Barlaz, M. (2009): Accumulation and fragmentation of plastic debris in global environments. - Philosophical Transactions of the Royal Society B 364: 1985-1998.

[4] Bonanno, G., Orlando-Bonaca, M. (2020): Marine plastics: what risks and policies exist for seagrass ecosystems in the Plasticene? - Marine Pollution Bulletin 158: 111425.

[5] Cauwenberghe, L. V., Claessens, M., Vandegehuchte, M. B., Mees, J., Janssen, C. R. (2013): Assessment of marine debris on the Belgian Continental shelf. - Marine Pollution Bulletin 73: 161-169.

[6] Claessens, M., Cauwenberghe, L. V., Vandegehuchte, M. B., Janssen, C. R. (2013): New techniques for the detection of microplastics in sediments and field collected organisms . -Marine Pollution Bulletin 70: 227-233.

[7] Department of Disease Control (2020): Daily COVID-19 report, Thailand information. https://data.go.th/dataset/covid--19daily (accessed 9 September 2021).

[8] Department of Marine and Coastal Resources (2013): Coastal Hydrographic. https://km.dmcr.go.th/th/c_51/d_1130. (Accessed 25 July 2021).

[9] Geyer, R., Jambeck, J. R., Law, K. L. (2017): Production, use, and fate of all plastics ever made. - Science Advances 3: 1-5.

[10] Gonulal, O., Oz, I., Gurasen, S. O., Qzturk, B. (2016): Abundance and composition of marine litter around Gokceada Island (Northern Aegean Sea). - Aquatic Ecosystem Health \& Management 19(4): 461-467.

[11] Haram, L. E., Carlton, J. T., Ruiz, G. M., Maximenko, N. A. (2020): A plasticene lexicon. - Marine Pollution Bulletin 150(110714).

[12] Jambeck, J. R., Geyer, R., Wilcox, C., Siegler, T. R., Perryman, M., Andrady, A., Narayan, R., Law, K. L. (2015): Plastic waste inputs from land into the ocean. - Science 347(6223): 768-771.

[13] Kumar, A. A., Sivakumar, R., Reddy, Y. S. R., Bhagya Raja, M. V., Nishanth, T., Revanth, V. (2016): Preliminary study on marine debris pollution along Marina beach, Chennai, India. - Regional Studies in Marine Science 5: 35-40.

[14] Lippiatt, S., Opfer, S., Arthur, C. (2013): Marine Debris Monitoring and Assessment. NOAA Technical Memorandum NOS-OR\&R-46.

[15] Marine Knowledge Database (2018): Brief policy recommendations situations and preventive approaches to solve marine and coastal waste problems. Documents under the project "Preparing a Brief Policy Recommendation on Urgent Issues on the National Maritime Interests

of Thailand." 
http://mrpolicy.trf.or.th/LinkClick.aspx ?fileticket $=$ TqcNIuZ6E7g\%3D\&tabid $=65 \& \mathrm{mid}=$ 401 (Accessed 9 July 2021).

[16] Maximenko, N., Corradi, P., Law, K. L., Van Sebille, E., Garaba, S. P., Lampitt, R. S., Galgani, F., Martinez-Vicente, V., Goddijn-Murphy, L., Veiga, J. M., Thompson, R. C., Maes, C., Moller, D., Löscher, C. R., Addamo, A. M., Lamson, M. R., Centurioni, L. R., Posth, N. R., Lumpkin, R., Vinci, M., Martins, A. M., Pieper, C. D., Isobe, A., Hanke, G., Edwards, M., Chubarenko, I. P., Rodriguez, G., Aliani, S., Arias, M., Asner, G. P., Brosich, A., Carlton, J. T., Chao, Y., Cook, A. M., Cundy, A. B., Galloway, T. S., Giorgetti, A., Goni, G. J., Guichoux, Y., Haram, L. E., Hardesty, B. D., Holdsworth, N., Lebreton, L., Leslie, H. A., Macadam-Somer, I., Mace, T., Manuel, M., Marsh, R., Martinez, E., Mayor, D. J., Le Moigne, M., Jack, M. E. M., Mowlem, M. C., Obbard, R. W., Pabortsava, K., Robberson, B., Rotaru, A. E., Ruiz, G. M., Spedicato, M. T., Thiel, M., Turra, A., Wilcox, C. (2019): Toward the integrated marine debris observing system. - Frontiers in Marine Science 6(447).

[17] Ministry of Tourism and Sports. (2020): Domestic Tourism Statistics ( Classify by region and province 2020). - https://mots.go.th/more_news_new.php?cid=594 (accessed 9 September 2021).

[18] Mobilik, J. M., Ling, T. Y., Husain, M. L., Hassan, R. (2016): Type and quantity of shipborne garbage at selected tropical beaches. - The Scientific World 2016(5126951).

[19] Ocean Conservancy Start a Sea Change (2009). Guide to Marine Debris and International Coastal Cleanup. - Department of Marine and Coastal Resources (translator to Thai).

[20] Okuku, E., Kiteresi, L., Owato, G., Otieno, K., Mwalugha, C., Mbuche, M., Gwada, B., Nelson, A., Chepkemboi, P., Achieng, Q., Wanjeri, V., Ndwiga, J., Mulupi, L., Omire, J. (2021): The impacts of COVID-19 pandemic on marine litter pollution along the Kenyan Coast: A synthesis after 100 days following the first reported case in Kenya. - Marine Pollution Bulletin 162(111840).

[21] Pervez, R., Wang, Y., Mahmood, Q., Zahir, M., Jattak, Z. (2020): Abundance, type, and origin of litter on No. 1 Bathing Beach of Qingdao, China. - Coastal Conservation 24(34).

[22] Pollution Control Department (2018): A Roadmap for Plastic Waste Management 20182030. - http://www.pcd.go.th/Info_serv/File/Plastic\%20Roadmap.pdf (accessed 30 July 2021).

[23] Pradit, S., Towatana, P., Nitiratsuwan, T., Jualaong, T., Jirajarus, M., Sornplang, K., Noppradit, P., Darakai, Y., Weerawong, C. (2020a): Occurrence of microplastics on beach sediment at Libong, a pristine island in Andaman Sea, Thailand. - ScienceAsia 46(2020).

[24] Pradit, S., Nitiratsuwan, T., Towatana, P., Jualaong, T., Sornplang, K., Noppradit, P., Jirajarus, M., Darakai, Y., Weerawon, C. (2020b): Marine debris accumulation on the beach in Libong, a small island in Andaman Sea, Thailand. - Applied Ecology and Environmental Research 18(4): 5461-5474.

[25] Pradit, S., Noppradit, P., Goh, B. P., Sornplang, K., Ong. M. C., Towatana, P. (2021): Occurrence of microplastics and trace metals in fish and shrimp from Songkla Lake, Thailand During the COVID-19 pandemic. - Applied Ecology and Environmental Research 19(4): 1085-1106.

[26] Royal Thai Government Gazette (2020): Regulation Issued under Section 9 of the Emergency Decree on Public Administration in Emergency Situations. - B. E. 2548(2005) (No. 1). 
[27] Rayon-Vina, F., Miralles, L., Fernandez-Rodrigues, S., Dopico, E., Garcia-Vazques, E. (2019): Marine litter and public involvement in beach cleaning: Disentangling perception and awareness among adults and children, Bay of Biscay, Spain. - Marine Pollution Bulletin 141: 112-118.

[28] Sheavly, S. B. (2007): National Marine Debris Monitoring Program: Final Program Report, Data Analysis and Summary. - Prepared for U. S. Environmental Protection Agency by Ocean Conservancy, Grant Number X83053401-02.

[29] Silva, A. L. P., Prata, J. C., Walker, T. R., Duarte, A. C., Ouyang, W., Barcelò, D., Rocha-Santos, T. (2021): Increased plastic pollution due to COVID-19 pandemic: Challenges and recommendations. - Chemical Engineering Journal 405(126683).

[30] Simeonova, A., Chuturkova, R. (2019): Marine litter accumulation along the Bulgarian Black Sea coast: categories and predominance. - Waste Management 84: 182-193.

[31] UNESCO (2019): United Nations Decade of Ocean Science for Sustainable Development (2021-2030). - https://en.unesco.org/ocean-decade (accessed 19 July 2021).

[32] United Nations (2019): Sustainable Development Goal 14. Conserve and sustainably use the oceans, seas and marine resources for sustainable development. https://sustainabledevelopment.un.org/sdg14 (accessed 19 July 2021).

[33] Veerasingam, S., Al-Khayat, J. A., Aboobacker, V. M., Hamza, S., Vethamony, P. (2020): Sources, spatial distribution and characteristics of marine litter along the west coast of Qatar. - Marine Pollution Bulletin 159(111478).

[34] Velavan, T. P., Meyer, C. G. (2020): The COVID-19 epidemic. - Tropical Medicine and International Health 25(3): 278-280. 